\title{
Across-shelf sediment transport: Interactions between suspended sediment and bed sediment
}

\section{Courtney K. Harris}

Virginia Institute of Marine Science

Patricia Wiberg

Follow this and additional works at: https://scholarworks.wm.edu/vimsarticles

Part of the Marine Biology Commons

\section{Recommended Citation}

Harris, Courtney K. and Wiberg, Patricia, "Across-shelf sediment transport: Interactions between suspended sediment and bed sediment" (2002). VIMS Articles. 284.

https://scholarworks.wm.edu/vimsarticles/284 


\title{
Across-shelf sediment transport: Interactions between suspended sediment and bed sediment
}

\author{
Courtney K. Harris ${ }^{1}$ and Patricia Wiberg \\ Department of Environmental Sciences, University of Virginia, Charlottesville, Virginia, USA \\ Received 12 September 2000; revised 9 July 2001; accepted 13 July 2001; published 30 January 2002.
}

[1] We use a two-dimensional, time-dependent sediment-transport model to quantify across-shelf transport, deposition, and sorting during wave-driven resuspension events characteristic of those that dominate sediment transport on many continental shelves. Decreases in wave-orbital velocities as water depth increases, and the resulting cross-shelf gradient in bed shear stress favor a net offshore transport of sediment. On wide, flat shelves (slopes $\sim 0.1 \%$ ), these gradients are low, and the depth to which the seabed is reworked depends mainly on bottom shear stress and local sediment availability. On narrow, steep shelves (slopes $\sim 0.5 \%$ ), however, the gradient in bottom stress generates significant cross-shelf suspended sediment flux gradients that create regions of net erosion and deposition. While the magnitude of waves generally determines the water depth to which sediment can be resuspended, erosional and depositional patterns on narrow shelves are sensitive to cross-shelf gradients in wave energy, nonlocal sediment availability, and the direction and magnitude of the cross-shelf current. During energetic waves, cross-shelf divergence of suspended sediment flux can create a coarsened, erosional area on the inner shelf that abuts a region of fine-grained sediment deposition on the mid-to-outer shelf. If currents are strongly shoreward, however, flux divergence leads to erosion over the entire shelf. INDEX TERMS: 4211 Oceanography: General: Benthic boundary layers, 3022 Marine Geology and Geophysics: Marine sediments-processes and transport, 4255 Oceanography: General: Numerical modeling, 4219 Oceanography: General: Continental shelf processes

\section{Introduction}

[2] On many shelves, including those off California and the U.S. mid-Atlantic coast, resuspension by energetic waves and currents is the dominant mechanism for sediment transport [Butman et al., 1979; Drake and Cacchione, 1985]. Water column flows then disperse suspended sediment along and across the shelf. While along-shelf transport often dominates sediment flux, the largest gradients in sediment flux are commonly across-shelf [Nittrouer and Wright, 1994]. These flux gradients may arise from spatial gradients in wave energy, current velocity, sediment properties, and/or from proximity to sediment sources. Cross-shelf divergences and convergences in sediment flux during transport events lead to net deposition or erosion of the seafloor and to cross-shelf changes in bed surface texture that have been difficult to quantify. Over longer timescales, these processes may contribute to the development of continental margin morphology and to textural patterns preserved in continental shelf deposits [Nittrouer and Wright, 1994].

[3] Waves tend to dominate bed shear stress on continental shelves when flow conditions are energetic enough to suspend sediment [Sternberg and Larsen, 1976; Smith and Hopkins, 1972; Drake and Cacchione, 1985]. The continental shelf lies between the nearshore zone and the shelf break. The nearshore zone is defined to be the area where nonlinear wave effects become important, shoreward of $\sim 20-30 \mathrm{~m}$ water depth. The shelf break is a change in the slope of the seabed generally found in water depths of $\sim 100-150 \mathrm{~m}$. Water depth on shelves therefore varies from $\sim 20-30 \mathrm{~m}$ on the inner shelf to $100-$

\footnotetext{
Virginia, USA.

Copyright 2002 by the American Geophysical Union. 0148-0227/02/2000JC000634
}

${ }^{1}$ Now at Virginia Institute of Marine Science, Gloucester Point,
$150 \mathrm{~m}$ on the outer shelf. For given surface wave conditions, the magnitude of the wave-generated bed shear stress decreases with increasing water depth so that cross-shelf gradients exist in wave-generated bed shear stress on shelves (Figure 1). These shear stress gradients are present on any wave-dominated sloping shelf, and they may produce gradients in suspended sediment flux that contribute to erosion and deposition across the shelf.

[4] Shelves worldwide display a variety of configurations. If we define shelf width as the distance between the $30-\mathrm{m}$ isobath and the shelf-slope break (nominally $\sim 120 \mathrm{~m}$ ), it varies from $\sim 20 \mathrm{~km}$ on some active margins to $200 \mathrm{~km}$ on some trailing edge margins [see, e.g., O'Grady et al., 1998]. Shelf steepness therefore ranges from slopes of $0.05 \%$ to $0.5 \%$. Wave-generated bed shear stress scales with water depth, so its cross-shelf gradient will vary by an order of magnitude when narrow, steep (slopes $\sim 0.5 \%$ ) and wide, flat (slopes $\sim 0.05 \%$ ) shelves are compared. This suggests that divergences of suspended sediment flux that arise from cross-shelf gradients in wavegenerated shear stress will also be more significant on narrow, steep shelves than on wide, flat ones. Because flux divergence leads to net erosion and deposition, we expect that narrow shelves will experience higher erosion and deposition rates than wider shelves.

[5] Rates and gradients of suspended sediment flux also depend on the availability of suspendable sediment, which generally varies across the shelf. Bed texture on many shelves grades from silty sand on the inner shelf to sandy silt or silt over the middle and outer shelf. Coarser, relict deposits are present on many outer shelves. Seabeds off of major rivers on the U.S. Pacific coast, including the Columbia, Eel, and Russian Rivers, commonly exhibit a distinct mid-shelf mud deposit that can be traced to fluvial sources [see, e.g., Nittrouer et al., 1979; Griggs and Hein, 1980; Field et al., 1992; Sommerfield and Nittrouer, 1999]. 


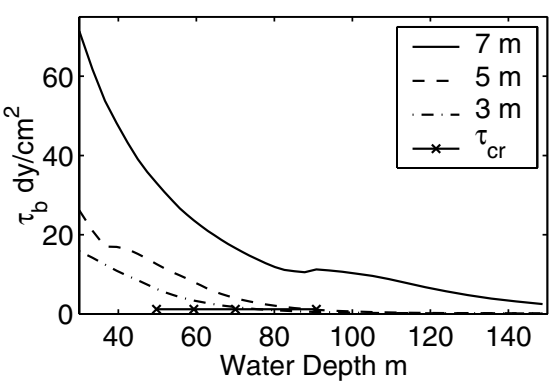

Figure 1. Bed shear stress $\left(\tau_{b}\right)$ calculated across a continental shelf for wave heights ranging from $H_{s i g}=3-7 \mathrm{~m}$ (see legend). Also shown are critical shear stress estimated for sediment samples from the Eel River Shelf, northern California.

[6] The patterns of cross-shelf texture observed on modern continental shelves have had thousands of years to develop. Recent observations, however, document the episodic nature of flood sediment deposition on the Eel River shelf and the modification to mid-shelf bed texture produced by single flood events [Sommerfield and Nittrouer, 1999; Wheatcroft and Borgeld, 2000]. One of the questions that motivates our study is whether a single storm, or series of storms, also has the potential to significantly modify the texture (grain size, sorting, grading) of the seabed on the continental shelf. Other questions we consider are the extent to which changes in seabed texture limit or enhance transport rates across the shelf during a single event and the amount of net erosion and/or deposition that a storm can produce. Recent analysis of sediment transport in channels (flumes and rivers), for example, shows that changes in bed texture can be the primary control on changes in transport rates [Rubin and Topping, 2001].

[7] To answer these questions observationally would require the correlation of relatively small gradients in cross-shelf transport with modifications to the seabed over the timescale of a single resuspension event. Small differences in sediment flux are difficult to discern from near-bed point measurements of suspended sediment concentration. They are dominated by local resuspension and fluctuations in forcing that mask the signals produced by such processes as advection and winnowing. Detecting changes in bed properties from seabed samples is also difficult and requires that samples preserve the characteristics of sediment near the bed surface (uppermost $1 \mathrm{~cm}$ ) and be taken shortly before and after the transport event, prior to significant biological reworking. It may also be difficult to sample the seabed at the spatial scales at which sediment texture varies.

[8] We use a two-dimensional, time-dependent model of shelf sediment transport to evaluate the ability of moderately sized resuspension events to modify the seabed. Likewise, we show that modifications to the seabed during an event impact water column transport. Calculations are carried out for idealized and observed wave-generated transport events on narrow and wide shelves with an initially uniform silty-sand bed. Settings having a mid-shelf mud deposit are also considered.

\section{Approach}

[9] Estimates of suspended sediment concentration and flux from continental shelf environments have typically been obtained from point measurements [see, e.g., Butman et al., 1979; Drake and Cacchione, 1985; Lyne et al., 1987; Sherwood et al., 1994; Cacchione et al., 1999; Ogston and Sternberg, 1999] and onedimensional models [see, e.g., Wiberg et al., 1994; Li and Amos, 1995, 2001; Harris and Wiberg, 1997]. While one-dimensional numerical models have often been found to approximate observed sediment concentrations and profiles, they are unable to predict net erosion and deposition and cannot resolve sediment flux diver- gence that may have significant implications for redistributing sediment across continental shelves.

[10] Calculations that include more than one spatial dimension can directly account for flux divergence and advection. A full three-dimensional model would be advantageous for examining shelves with along-shelf variation in sediment supply, wave energy, or oceanographic circulation patterns. On many shelves, however, the spatial gradients in both bed shear stress and sediment size are much larger in the cross-shelf direction than in the along-shelf direction. During a typical wave resuspension event ( $\sim 3-5$ days), suspended sediment is likely to encounter larger gradients in sediment size and flow energy in the cross-shelf than in the alongshelf direction, even though alongshelf velocities are typically $\sim 2-5$ times higher than cross-shelf velocities. For such shelves, redistribution of continental shelf sediment by transport in the bottom boundary layer is well represented by a two-dimensional (cross-shelf and vertical), time-dependent model of shelf sediment transport and bed evolution.

[11] We have extended a well-tested, one-dimensional resuspension model [see, e.g., Wiberg et al., 1994; Cacchione et al., 1999] formulated for the bottom boundary layer of continental shelves to a two-dimensional, time-dependent model of shelf sediment transport [Harris and Wiberg, 2001]. Calculated divergences in suspended sediment flux are used to estimate net erosion, deposition, and textural modification of the seabed surface during resuspension events. The following summarizes the model; see Harris and Wiberg [2001]; Harris [1999] for details.

[12] We calculate suspended sediment concentrations and fluxes using the two-dimensional, time-dependent advection-diffusion equation applied to suspended sediment in the bottom boundary layer of the continental shelf [see, e.g., Smith, 1977]

$$
\frac{\partial C_{s}}{\partial t}=-u \frac{\partial C_{s}}{\partial x}+\frac{\partial}{\partial x}\left(K_{x} \frac{\partial C_{s}}{\partial_{x}}\right)+w_{s} \frac{\partial C_{s}}{\partial z}+\frac{\partial}{\partial z}\left(K_{z} \frac{\partial C_{s}}{\partial z}\right) .
$$

Here $C_{s}$ is the suspended sediment concentration, $u$ is flow velocity, $w_{s}$ is sediment settling velocity ( $w_{s}>0$ by convention), and $K_{x}$ and $K_{z}$ are the horizontal and vertical diffusion coefficients, respectively. The eddy diffusivity, $K_{z}$, is a function of height above the bed and shear stress and is assumed equal to the eddy viscosity of the fluid. The model uses one horizontal $(x)$ and one vertical $(z)$ direction and assumes uniform conditions in the second horizontal dimension. For this study, the horizontal direction is oriented across the shelf. The model domain is the bottom boundary layer of a continental shelf, which includes a thin wave boundary layer adjacent to the bed $(\sim 10 \mathrm{~cm}$ thick) and the bottom Ekman layer (tens of meters thick). Sediment is typically entrained into the water column by wave-generated bed shear stresses, transported by bottom boundary layer currents, and eventually settles back to the bed under less energetic conditions.

[13] Boundary conditions are chosen in an attempt to realistically portray sediment transport in the bottom boundary layer between water depths of 30-100 m. Sediment may enter or leave the model domain through exchange with the seabed, but other boundaries (upper, inshore, and offshore) are closed. The top of the model grid is one-half the water depth at each location along the transect. Sediment concentration and the vertical diffusion coefficient are both low at this level, so that sediment transport into overlying water should be minimal. The cross-shelf boundaries are placed far from the region of interest or in locations where transport of sediment is limited by the lack of available fine sediment (inshore boundary) or low wave energy (offshore boundary). Because the calculations are sensitive to treatment of the nearshore boundary [Harris and Wiberg, 2001], a buffer zone $\sim 24 \%$ of the shelf width is added to the inner-shelf portion of the model grid (indicated to the left of $0 \mathrm{~km}$ in Figure 2). Water depth is held constant in the buffer zone, but sediment grain size is 


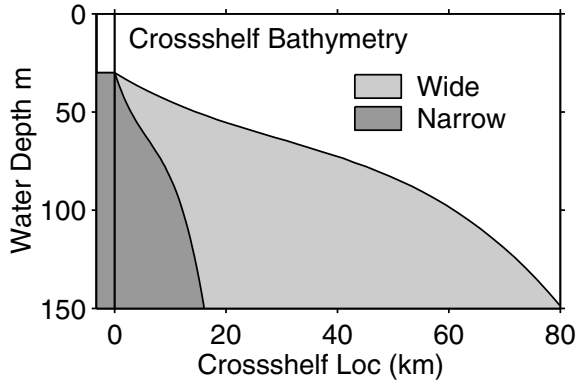

Figure 2. Cross-shelf bathymetry for wide and narrow shelves. Flat area shoreward of $0 \mathrm{~km}$ indicates presence of buffer zones, 16.5 and $3.3 \mathrm{~km}$ wide for the wide and narrow shelf, respectively.

coarsened toward the nearshore edge to minimize transport. Because sediment can be exchanged between the buffer zone and the region of interest, the buffer zone serves as a limited source of fine-grained sediment to the shelf.

[14] Calculated suspended sediment concentrations and fluxes are related to modifications in bed texture using the erosion equation, which conserves sediment mass between the water column and the sediment bed:

$$
\frac{\partial \eta}{\partial t}=-\frac{1}{C_{b}}\left(\frac{\partial q_{s x}}{\partial x}+\frac{\partial V_{s}}{\partial t}\right)
$$

where $\eta$ is the elevation of the bed surface, $C_{b}$ is bed sediment concentration (1-porosity), $q_{s x}$ is depth-integrated suspended sediment volume flux in the cross-shelf direction $\left(q_{s x}=\int_{0}^{h} C_{s} u d z\right)$, $V_{s}$ is depth-integrated volume of suspended sediment $\left(V_{s}=\right.$ $\int_{0}^{h} C_{s} d z$ ), and $h$ is bottom boundary layer height. To calculate sediment flux, erosion, and deposition on a seabed that contains a range of sediment sizes, equations (1) and (2) are independently applied to each of several grain size classes across the shelf.

[15] Previous implementations of similar, one-dimensional resuspension models noted that bottom boundary layer flows are capable of maintaining more fine sand and silt in suspension than typical seabeds can supply [Lyne et al., 1987; Kachel and Smith, 1989; Wiberg et al., 1994]. Suspended sediment profiles may therefore not be equilibrated with the local seabed but may also reflect sediment transported into a location. For these reasons both bed armoring processes and upstream conditions are likely to impact suspended sediment concentrations on continental shelves.

[16] Erosion from each point along a shelf transect is limited to the amount of each grain size present in the active layer of sediment at the bed surface. Throughout a resuspension event, the grain size distribution within the surficial layer is modified to account for erosion and deposition of sediment. Sediment size distributions are also updated to reflect exchange between the active layer and the underlying bed when their boundary moves upward or downward owing to erosion, deposition, or a change in thickness of the active layer. The thickness of the surficial layer of active, available sediment is assumed to be proportional to the excess shear stress of the flow [Harris and Wiberg, 2001]. Different formulations are used to estimate the active layer thickness for sandy and muddy beds to account for differences in the way that these substrates respond to energetic flows [Harris and Wiberg, 2001]. The active-layer thickness for mixed-grain-size beds is calculated using an average of the sand and mud formulations, weighted by the percent of sand in the surface layer. Estimates of active-layer thickness tend to be larger during energetic conditions and over sandy beds with active ripples. Active layer depths typically range from a few millimeters over the middle and outer-shelf to a few centimeters over the inner shelf.

[17] In this paper, two cross-shelf transects are used to demonstrate the influence of shelf geometry and, in particular shelf width, in determining cross-shelf transport patterns. Each of the shelf transects is subjected to a variety of wave and current velocities. Both transects are $30 \mathrm{~m}$ deep at the innershelf boundary and $150 \mathrm{~m}$ deep at the off-shelf boundary (Figure 2). The shelves differ in that one is a "narrow, steep" shelf, with a shelf width of $20 \mathrm{~km}$, and the other is a "wide, flat" shelf that is $100-\mathrm{km}$ wide. The narrow shelf is based on the bathymetry of the Eel River shelf, northern California, and has an average slope of $0.5 \%$, representative of shelves on the Pacific coast of the United States. The wide shelf geometry is 5 times wider, giving an average slope of $0.1 \%$, similar to shelves on the U.S. Atlantic coast. Sediment texture across both modeled transects is initialized to be an ungraded, poorly sorted, silty sand bed (Table 1). An additional case is considered in section 4 to explore transport processes on shelves that have a mid-shelf mud bed, similar to those observed in depositional areas off of river mouths in the western United States such as the Eel River [Borgeld, 1985], the Russian River [Field et al., 1992], and the Columbia River [Nittrouer et al., 1979]. For this case, the silty grain size distribution in Table 1 is used to represent the sediment texture of the mid-shelf mud deposit.

[18] The hydrodynamic properties of the sediment are chosen to reflect the properties of the cohesive and noncohesive size fractions in the surface active layer (Table 1). A minimum settling velocity of $0.1 \mathrm{~cm} / \mathrm{s}$ is assumed for sediment finer than $45 \mu \mathrm{m}$ (Table 1) based on observations of flocculated sediment size and settling velocity in fine-grained marine settings [Sternberg et al., 1999; Hill and McCave, 2001]. Observations of resuspension indicate that fine-grained marine sediments exhibit cohesive behavior. To account for this, a minimum critical shear stress of 1 dyne $/ \mathrm{cm}^{2}$ is assumed, following previous work [Wiberg et al., 1994; Harris and Wiberg, 1997; Maa et al., 1998].

[19] Water column transport and modifications to the seabed are quantified using several values. The volume per unit area suspended at a location, $V_{s}=\int_{0}^{h_{\text {geo }}} C_{s} d z\left(\mathrm{~cm}^{3} / \mathrm{cm}^{2}\right)$, represents the thickness of the layer that would be deposited if all sediment settled out of suspension, disregarding the porosity of the seabed. Because we neglect cross-shelf variations in current velocity, sediment flux scales with $V_{s}$; we therefore use $V_{s}$ as a proxy for flux. The cumulative cross-shelf flux represents the time-integrated sediment flux at a given location, i.e., $\int q_{s x} d t$. Changes to the elevation of the seabed $(\Delta \eta)$ are calculated by time-integrating equation (2). Textural changes are reported using sediment budgets or sediment size distribution of the sea bed. The depth to which the sediment bed is modified by a resuspension event is termed an "event bed" or

Table 1. Sediment Size Distributions and Properties ${ }^{\mathrm{a}}$

\begin{tabular}{lcccc}
\hline Nominal Size, $\phi$ & 5.50 & 4.25 & 3.50 & 2.00 \\
\hline Size range, $\mu \mathrm{m}$ & $<45$ & $45-63$ & $63-125$ & $>125$ \\
Size range, $\phi$ & $6.6-4.5$ & $4.5-4.0$ & $4.0-3.0$ & $3.0-1.0$ \\
& \multicolumn{5}{c}{ Sediment Properties } \\
\multicolumn{5}{c}{0.42} \\
$w_{s}, \mathrm{~cm} / \mathrm{s}$ & 0.10 & 0.16 & 16 & 2.23 \\
$\tau_{c r}$, dyne $/ \mathrm{cm}^{2}$ & 1.00 & 1.00 & 1.25 \\
\multicolumn{5}{c}{ Fraction of the Bed } \\
Silty-Sand & 0.26 & 0.09 & 0.31 & 0.33 \\
Silt & 0.82 & 0.11 & 0.06 & 0.01 \\
\hline
\end{tabular}

${ }^{\text {a }}$ Provides settling velocity $\left(w_{s}\right)$, critical shear stress $\left(\tau_{c r}\right)$, and fraction within the silty sand and silt beds for each grain size class. 


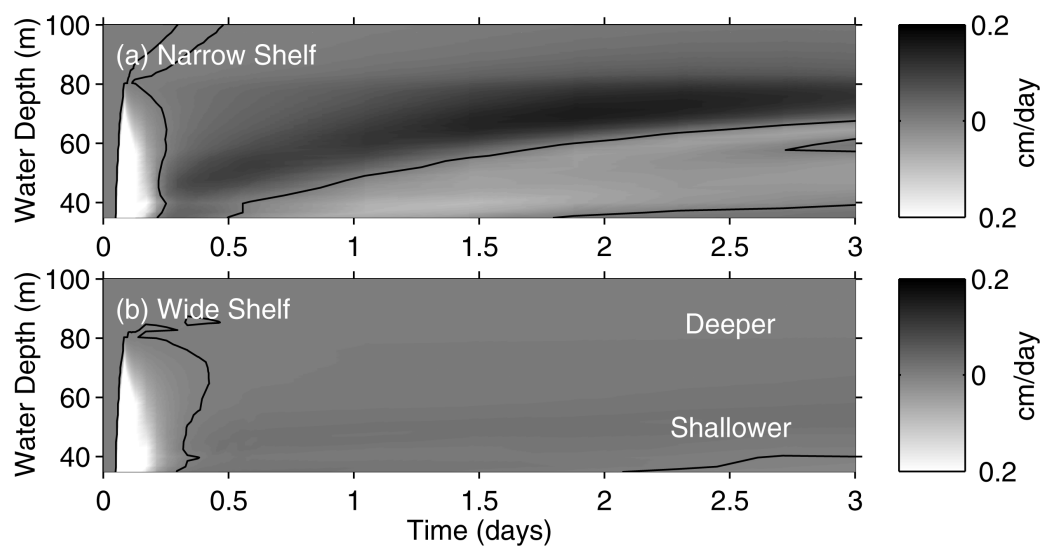

Figure 3. Deposition ( $>0$, dark areas) and erosion ( $<0$, light areas) rates calculated under steady energetic flows as a function of water depth and time for a (a) narrow and (b) wide shelf.

"storm bed" thickness that includes the surface active layer and redeposited material.

\section{Results}

[20] Calculations are completed for two types of flow regimes. The cross-shelf response to steady wave and current velocities is calculated to determine the timescales of entrainment, redistribution, and redeposition under energetic waves. The cross-shelf transects are then subject to realistic wave and current velocity time series to demonstrate how fluctuations in forcing influence transport patterns.

\subsection{Steady Forcing}

[21] This example illustrates the rate at which sediment is entrained from the bed and transported across a narrow and a wide shelf in the absence of confounding effects of fluctuating wave and current conditions. Wave energy is increased from an initially low value for the first hour, after which significant wave height is held steady $\left(H_{\text {sig }}=5 \mathrm{~m}\right)$. Mid-water column (geostrophic) currents are a constant $10 \mathrm{~cm} / \mathrm{s}$ directed off-shelf and poleward at a $45^{\circ}$ angle (i.e., $7 \mathrm{~cm} / \mathrm{s}$ off-shelf and $7 \mathrm{~cm} / \mathrm{s}$ poleward). We describe the response of the suspended sediment field to the wave event and then relate water column transport to changes in seabed texture and net erosion.

[22] During the first few hours of the event, sediment is eroded from the bed in water depths less than $80 \mathrm{~m}$, where the critical shear stress for suspension is exceeded (Figure 3). Suspended sediment volumes increase rapidly at the onset of energetic waves, and calculations made during this time at equivalent water depths on the narrow and wide shelves are nearly identical (figure 4). Calculations for the wide and narrow shelves begin to diverge as redistribution across gradients in bed shear stress and
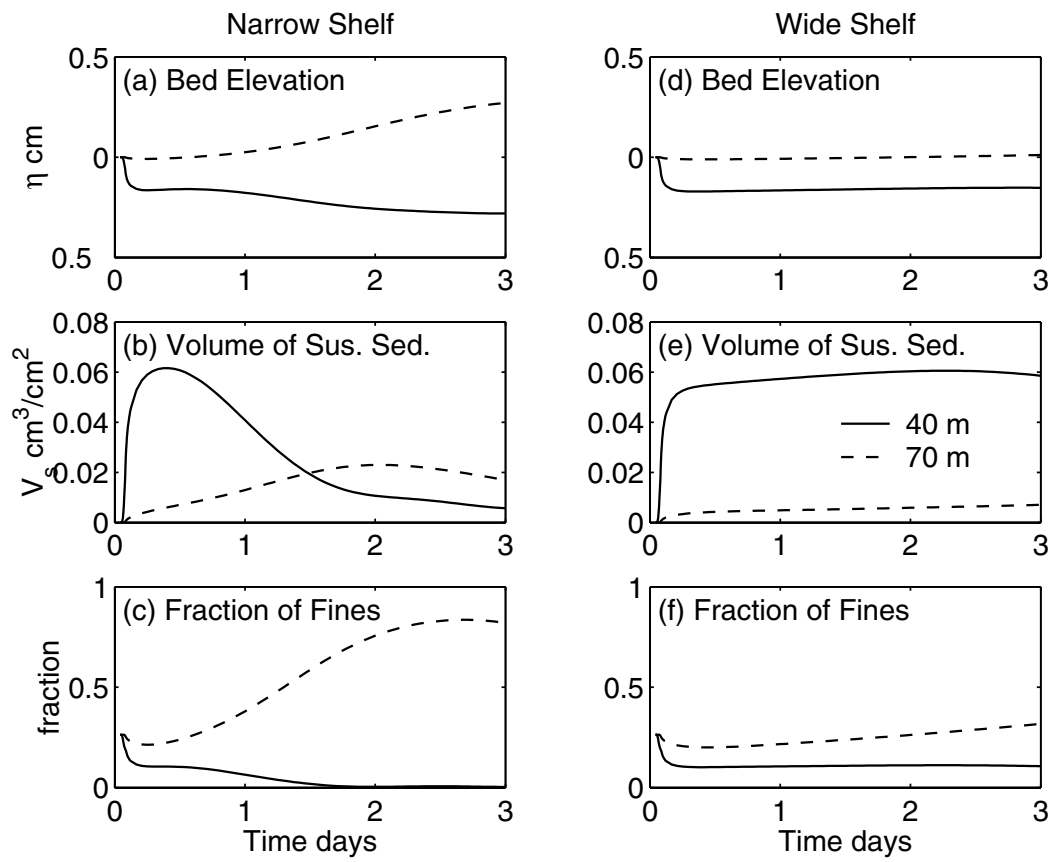

Figure 4. Calculations made over a 3-day period of steady waves and currents for a narrow shelf transect (Figures $4 \mathrm{a}-4 \mathrm{c}$ ) and wide shelf transect (Figures 4d-4e). Results shown for two water depths: $40 \mathrm{~m}$ (solid lines) and $70 \mathrm{~m}$ (dashed lines). ( $a, d)$ Bed elevation; $>0$ indicates deposition. (b, e) Volume of sediment suspended. (c, f) Fraction of active layer sediment finer than $45 \mu \mathrm{m}$. 
sediment availability become significant on the narrow shelf (Figure 4). Within a day sediment on the narrow shelf is advected 5-7 km, from water depths of $40 \mathrm{~m}$ to a depth of $70 \mathrm{~m}$. A 5-7 $\mathrm{km}$ traverse on the wide shelf only carries sediment from a depth of $40 \mathrm{~m}$ to $47 \mathrm{~m}$. At day 0.5 , suspended sediment concentrations at a $40 \mathrm{~m}$ site on the narrow shelf are slightly higher than at the same depth on the wide shelf reflecting the proximity of the energetic inner shelf (Figures $4 \mathrm{~b}$ and $4 \mathrm{e}$ ). Within a day, suspended sediment concentrations decrease at the $40 \mathrm{~m}$ site on the narrow shelf, as the supply of fine-grained material on the inner shelf is depleted. Suspended sediment flux is thus shown to be sensitive to the availability of sediment, and, on narrow shelves, to nonlocal, upstream conditions.

[23] Given the imposed steady forcing and off-shelf flow, general patterns of seabed modification are predictable for this case, but the rates at which the changes occur can only be obtained using a quantitative approach. Rates of erosion and textural change depend on the thickness of the surficial layer from which sediment is entrained. In this example, resuspension under moderate waves and currents decreases the silt-size fractions from the surficial layer, which has a thickness of a few centimeters or less, within hours of the onset of transport (Figures $4 \mathrm{c}$ and $4 \mathrm{f}$ ). Erosion is confined to be shoreward of the water depth where the bed shear stress equals the critical shear stress $(80 \mathrm{~m}$ in this example), but deposition occurs at sites shallower than $80 \mathrm{~m}$ (Figure 3). The offshelf flows imposed in this case carry sediment toward deeper, less energetic sites that are unable to maintain the delivered load in suspension. As the energetic conditions persist, this causes redeposition of fine sediment on the middle portion of the narrow shelf (Figures $3 \mathrm{a}$ and $4 \mathrm{c}$ ). Within 12 hours on the narrow shelf, the erosional and redepositional zones begin to migrate "downstream" (i.e., offshore) as the inner shelf is depleted of fines (Figure 3a). For mixed-grain-size beds, an erosional zone is associated with each sediment size class and is located in deeper water for the more easily suspendable sediment sizes. This creates erosional and depositional patches for each grain size. The wide shelf does not exhibit as dramatic a time-dependence because the advection length-scale of the event is small relative to the spatial gradients in wave energy.

[24] In summary, energetic waves and steady currents modify seabed texture on both the narrow and wide shelves within hours. Winnowing coarsens the inner shelf of both systems. For this case of off-shelf flow, flux convergence enhances cross-shelf size grading on the narrow shelf by redepositing fine sediment on the middle shelf region. Seabed modifications such as winnowing and redeposition, in turn, impact sediment transport rates by modifying the availability of fine sediments.

\subsection{Realistic Waves and Currents}

[25] The energetic waves and currents that drive actual resuspension events may persist for a few hours or days, but they are usually not constant for the length of time considered in the previous section. Wave height and current speed typically fluctuate on the timescale of hours. Even for an event with a net offshore flow, as in the previous example, current velocities may be directed toward shore for a significant portion of a storm due to tides or changes in subtidal current direction.

[26] To examine flux divergence patterns over the timescale of a resuspension event, the cross-shelf transects shown in Figure 2 are subjected to forcing conditions derived from measurements of waves and currents on the Eel River shelf, northern California. The 10-day time series used to drive these calculations includes four wave events, with peak wave heights of $8 \mathrm{~m}$ (Figure 5). Mean current speed is $18.0 \mathrm{~cm} / \mathrm{s}$, and net current velocities are $2.5 \mathrm{~cm} / \mathrm{s}$ and directed off-shelf and equatorward. The cross-shelf component of velocity varies between $\pm 20 \mathrm{~cm} / \mathrm{s}$, and is directed toward shore for $54 \%$ of the time period. Estimates of bed shear stress indicate
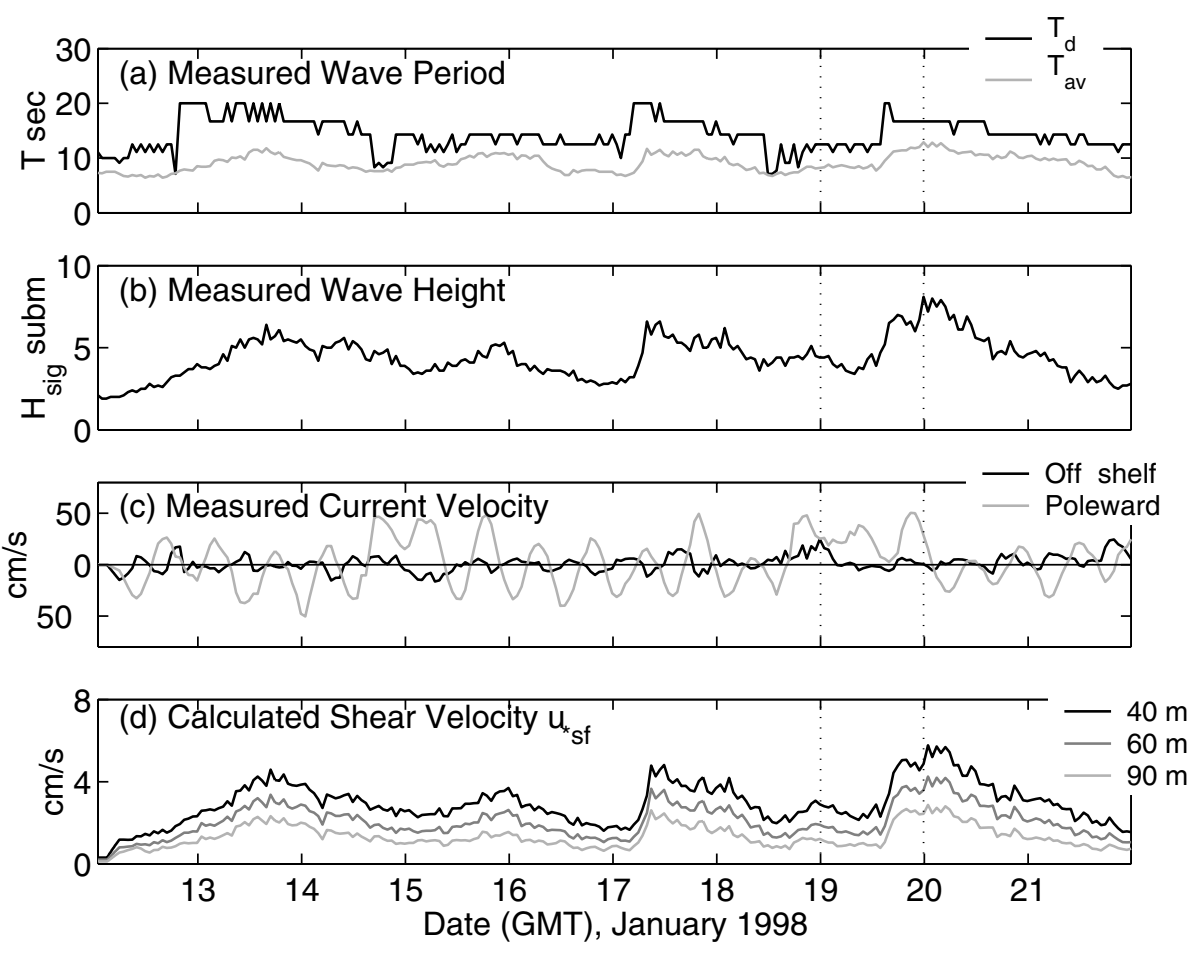

Figure 5. Waves and currents used to drive model calculations. (a, b) Waves measured by NDBC buoy 46022 (available at http://www.nodc.noaa.gov/BUOY/buoy.html). (c) Geostrophic currents; velocities measured $100 \mathrm{cmab}$ (centimeters above bed) [Ogston and Sternberg, 1999] extrapolated using a drag law. Values $>0$ indicate offshore or poleward flow. (d) Calculated skin-friction shear velocities for three water depths (see legend). Dotted lines indicate dates when waves are most energetic (20 January) and flux calculations are highest (19 January). 

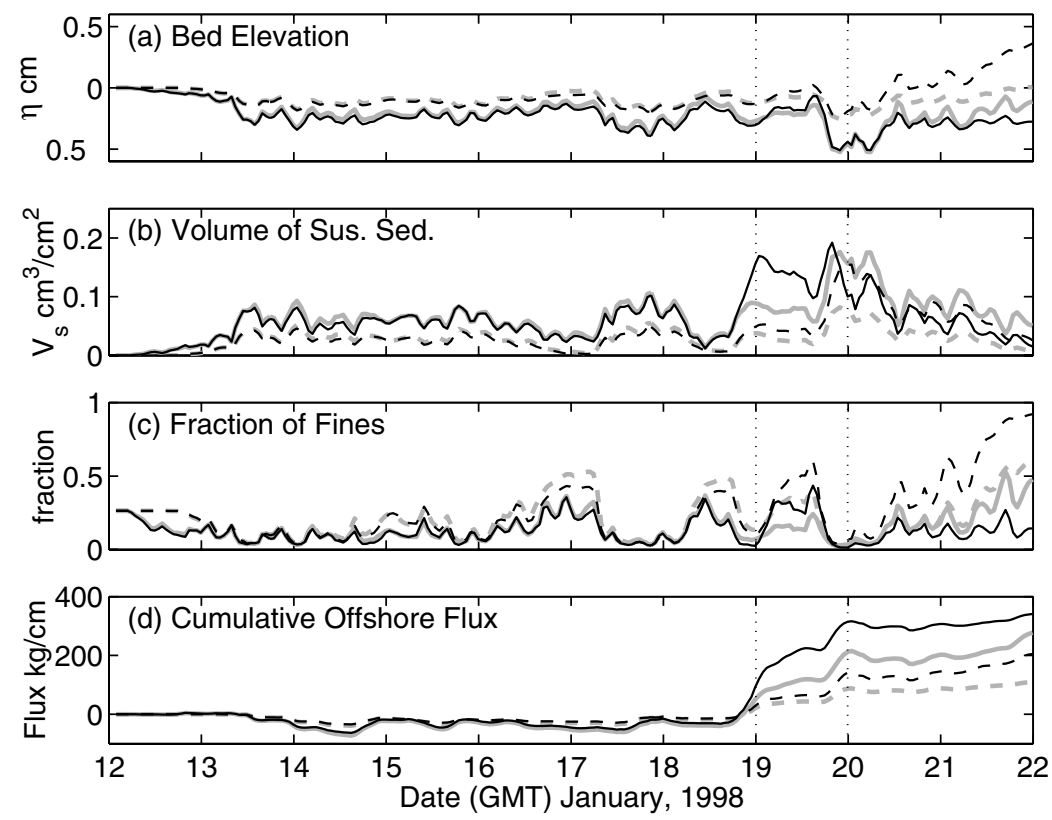

Figure 6. (a) Calculated bed elevation water depths of $40 \mathrm{~m}$ (solid lines) and $70 \mathrm{~m}$ (dashed lines) during the conditions shown in figure Figure 5. (b) Volume of suspended sediment. (c) Fraction of surface sediment of finest grain size $(<45 \mu \mathrm{m})$. (d) Cumulative cross-shelf flux. Grey lines calculated for the wide shelf; dark lines for the narrow shelves. Dotted lines drawn for times when waves are most energetic (20 January) and flux calculations are highest (19 January).

that flows are energetic enough to suspend fine-grained sediments $\left(u_{*_{c r}}=1 \mathrm{~cm} / \mathrm{s}\right)$ throughout this event at the inshore boundary $(30 \mathrm{~m})$ and during about a third of the time series at a water depth of $90 \mathrm{~m}$ (Figure $5 \mathrm{~d}$ ).

[27] The timing of storm waves and currents has a dramatic influence on sediment suspension and bed response (Figure 6). The largest suspended sediment concentrations occur when current velocities and wave energy are high and the bed surface is enriched with fine-grained sediment, on about January 19 and 20. As in the case of steady waves and currents, suspended sediment volumes calculated for the narrow shelf are more affected by redistribution and sediment availability than for the wide shelf (Figure 6). This difference, however, is somewhat masked by the response of both shelf transects to fluctuations in forcing that dominate the calculated time series.

[28] The use of realistic forcing results in higher instantaneous erosion and deposition rates compared to cases that use similar wave heights and mean current velocities but which do not include the fluctuations, particularly of currents, present in actual shelf environments. Modifications to seabed texture, however, are similar for the steady and fluctuating cases. As in the steady-flow case, high shear stresses combined with net off-shelf-directed flow remove fine sediment from the shallow portion of the model grid and transport it to the mid- and outer-shelf, where it is deposited as a fining upward layer (Figures 7 and 8). Fluctuations in waves and currents create down core variability in mean grain size (Figures 7 and 8). The model predicts more erosion and deposition on the narrow shelf, where the spatial derivative of flux divergence is high.

[29] The shelf sediment budget for this event illustrates the ability of energetic waves and currents to redistribute sediment. The net amount of a grain size that is added to the shelf site $\left(Q_{\text {in }}-Q_{\text {out }}\right.$ in Table 2$)$ equals the total deposition on the shelf. The finest size class $(<45 \mu \mathrm{m})$ accounts for most of the redistributed sediment, with the biggest source of sediment being the inner shelf (Table 2). Deposition is concentrated on the midto-outer shelf, indicating that the shallower regions of the shelf do not effectively retain silts and fine sands. Though less significant on the wide shelf within the 10-day period modeled, mid-shelf deposition is also favored on the wide shelf (Table 2). The cumulative effect of many wave-dominated resuspension events would be to remove silts and sands from the inner shelf and deposit them over the mid-to-outer shelf.

[30] To determine the sensitivity of patterns of shelf-redistribution to the direction of the net current, the calculations were repeated using a current velocity that was rotated by $180^{\circ}$, so that the net current was poleward and shoreward. With this driving current, the system experiences net erosion throughout the model domain and delivers sediment toward the inner shelf (Table 2). Shoreward flows carry sediment toward increasingly energetic environments that are able to maintain sediment loads in suspension so that there is no region of flux convergence and deposition. Our model cannot predict the fate of sediment transported to the inner shelf. Such sediment would either become mixed into nearshore sands, form a transient inner shelf deposit, or remain suspended until off-shelf flows occur.

\section{Discussion}

[31] Waves generally dominate bed shear stress and determine the times and locations where resuspension is possible, but sediment transport on the shelf strongly depends on current velocities and bed sediment properties. The availability of fine sediment in the seabed is usually limited to the point where the bed cannot supply as much of this sediment as the bottom boundary layer is able to maintain in suspension. Here we consider the roles of currents and seabed texture in cross-shelf transport and bed evolution.

\subsection{Sensitivity to Driving Waves and Currents}

[32] Continental shelf environments often have sufficient wave energy to suspend fine-grained sediment, particularly at inner- and mid-continental shelf water depths. For example, suspension thresholds are exceeded $\sim 48$ days/year on the $60 \mathrm{~m}$ isobath of the Russian River shelf [Sherwood et al., 1994] and 44 days per year on the New York Bight $[25 \mathrm{~mm}$ isobath, see Harris and Signell, 1999]. Wave orbital velocities, and thereby bed shear 

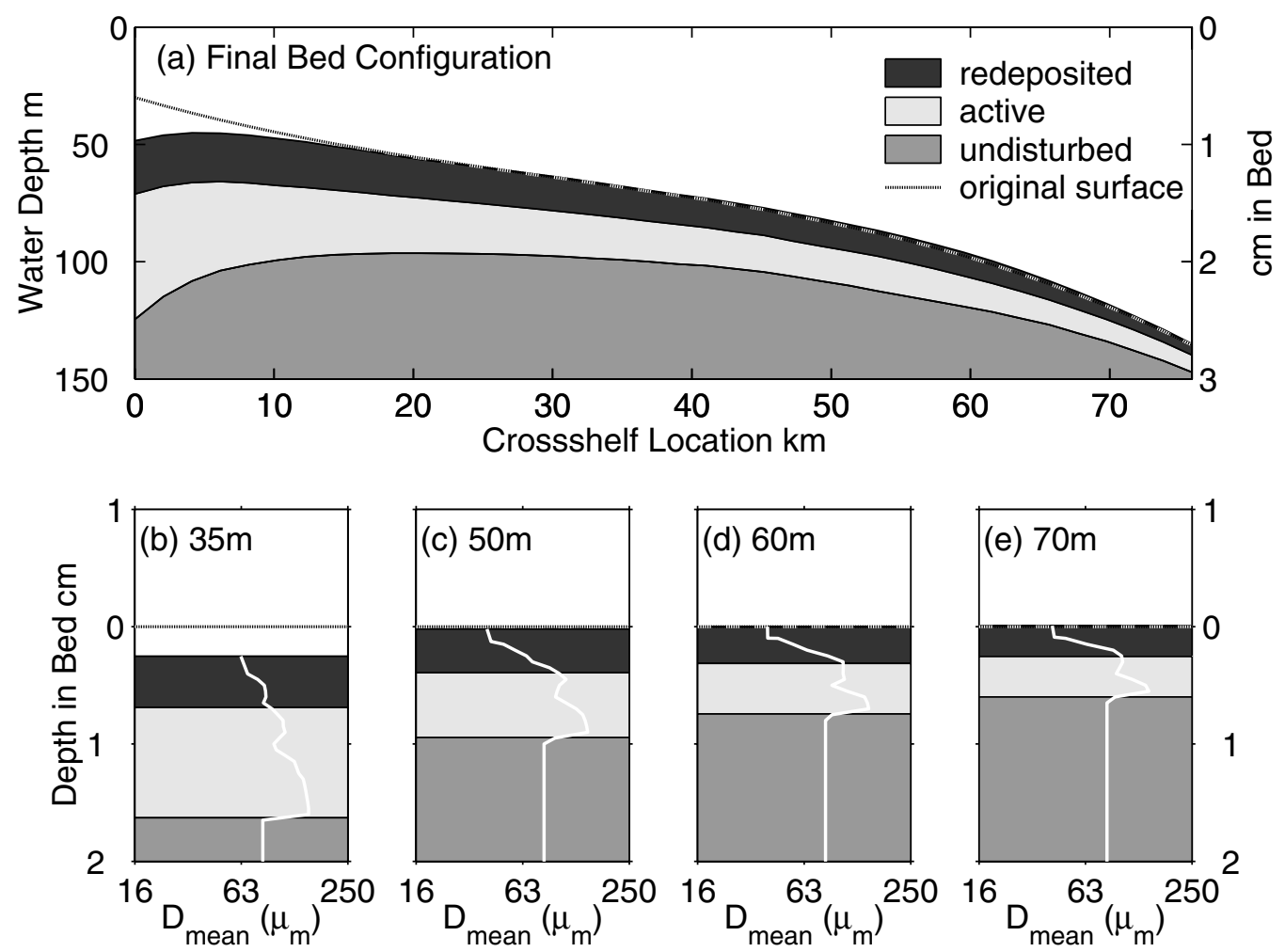

Figure 7. Final configuration of wide, flat shelf as reworked by realistic time series in Figure 5. Black represents sediment that was entrained, transported, and deposited during event. Light gray sediment was reworked by winnowing, but not suspended. Medium gray sediment was unaffected. (a) Cross-shelf erosion, deposition, and reworking with depth in bed (right vertical axis) plotted against cross-shelf location (horizontal axis). Dash-dot line represents water depth (left axis) versus cross-shelf location. (b-e) Small-scale bed grading shown for several water depths, as illustrated by mean grain-size in $\mathrm{s}$ with depth in bed (white lines).
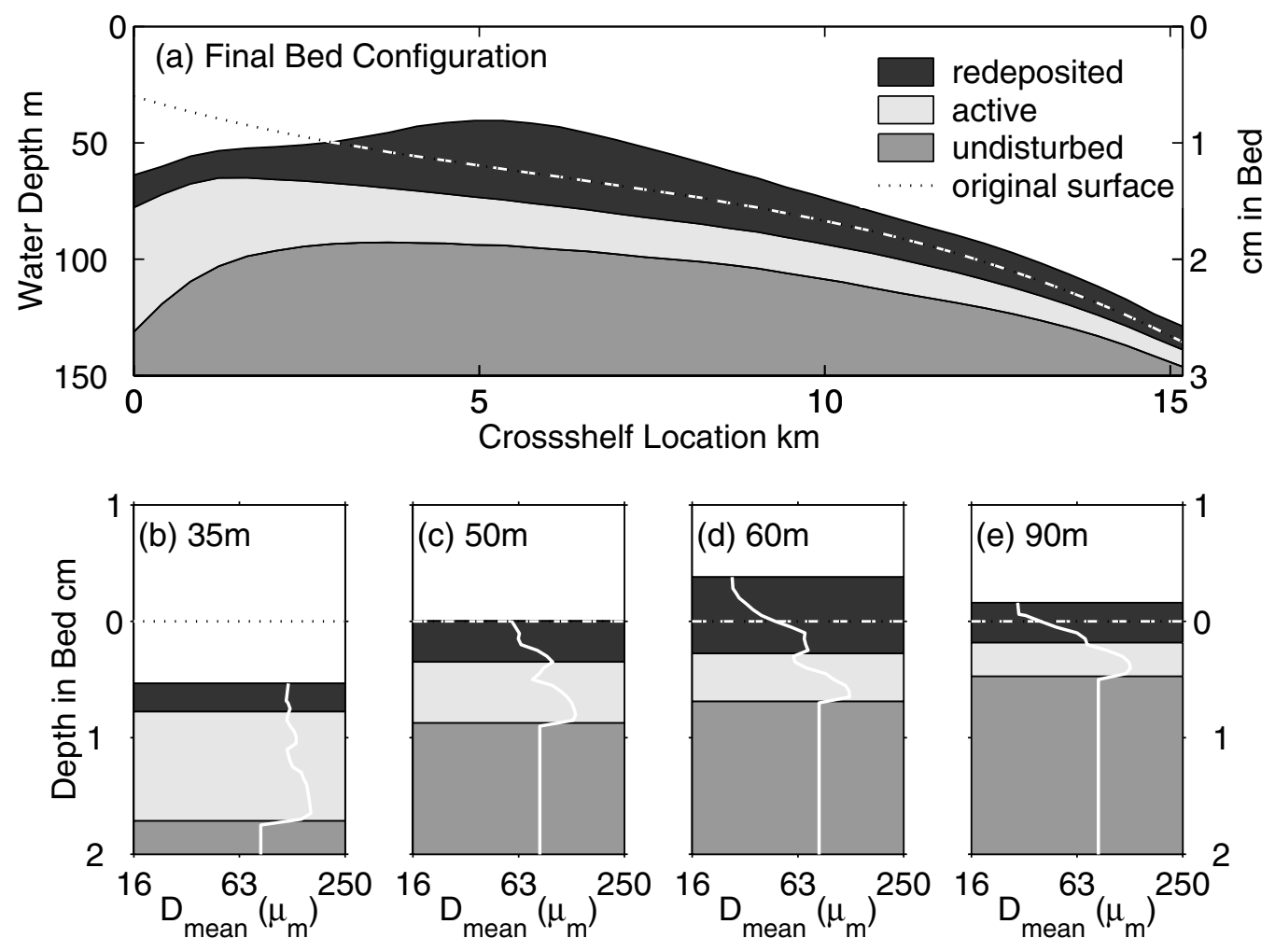

Figure 8. Final configuration of narrow, steep shelf as reworked by realistic time series in Figure 5. See Figure 7 for explanation of Figures $8 \mathrm{a}-8 \mathrm{e}$. 
Table 2. Calculated Sediment Budgets ${ }^{\mathrm{a}}$

\begin{tabular}{|c|c|c|c|c|}
\hline \multirow[b]{2}{*}{ Model Run } & \multicolumn{4}{|c|}{ Grain Size, $\mu \mathrm{m}$} \\
\hline & $<45$ & $45-63$ & $63-125$ & $>125$ \\
\hline \multicolumn{5}{|c|}{ Narrow Shelf } \\
\hline$Q_{\text {in }}^{\mathrm{b}}$ & 24.9 & 2.7 & 2.3 & 0.004 \\
\hline$Q_{\text {out }}^{\mathrm{b}}$ & 5.1 & 0.7 & 0.2 & 0 \\
\hline Deposition: Inner-mid ${ }^{\mathrm{c}}$ & -4.5 & -1.2 & 0.6 & 0.003 \\
\hline Deposition: Mid-outer ${ }^{\mathrm{c}}$ & 24.3 & 3.1 & 1.5 & 0.001 \\
\hline \multicolumn{5}{|c|}{ Wide Shelf } \\
\hline$Q_{\text {in }}^{\mathrm{b}}$ & 18.4 & 4.7 & 2.3 & 0.004 \\
\hline$Q_{\text {out }}^{\mathrm{b}}$ & 2.0 & 0.4 & 0.1 & 0 \\
\hline Deposition: Inner-mid ${ }^{c}$ & 1.4 & 1.1 & 0.9 & 0.003 \\
\hline Deposition: Mid-outer ${ }^{\mathrm{c}}$ & 14.6 & 3.1 & 1.3 & 0.001 \\
\hline \multicolumn{5}{|c|}{ Narrow Shelf, Reversed Currents } \\
\hline$Q_{\text {in }}^{\mathrm{b}}$ & -13.4 & -3.1 & -2.0 & -0.004 \\
\hline$Q_{\text {out }}^{\mathrm{b}}$ & -1.5 & -0.2 & -0.1 & 0 \\
\hline Deposition: Inner-mid ${ }^{\mathrm{c}}$ & -4.6 & -1.1 & -0.8 & -0.003 \\
\hline Deposition: Mid-outer ${ }^{\mathrm{c}}$ & -7.1 & -1.8 & -1.1 & 0.001 \\
\hline
\end{tabular}

${ }^{\mathrm{a}}$ Sediment inventory reported as $\mathrm{g} / \mathrm{cm} \times 10^{4}$ (mass of sediment per unit width of shelf). Budgets calculated for time series in Figure 5 for the narrow and wide shelves, and for the narrow shelf with current velocities reversed.

${ }^{\mathrm{b}}$ Flux into model domain from nearshore $\left(Q_{\text {in }}\right)$, and from model domain to continental slope $\left(Q_{\text {out }}\right)$ calculated at 30 and $125 \mathrm{~m}$, respectively. Positive fluxes indicate off-shore transport, negative fluxes indicate shoreward transport.

${ }^{\mathrm{c}}$ Net deposition calculated for inner-mid shelf and mid-outer shelf, defined as follows. Inner-mid shelf: water depths $30-50$ $\mathrm{m} ; 2.9 \mathrm{~km}$ wide on narrow shelf, $14.4 \mathrm{~km}$ wide on wide shelf. Mid-outer shelf: water depths $50-125 \mathrm{~m}, 11.5 \mathrm{~km}$ and 57.5 $\mathrm{km}$ wide on narrow and wide shelves, respectively. Negative values indicate net erosion.

stress, increase as water depth decreases. The shoreward increase in shear stress is larger than the shoreward increase in critical shear stress observed, for example, in sediments on the Eel River Shelf (Figure 1). As a result, silts and fine sands on the inner shelf are suspended more frequently and under conditions of higher bed shear stress than they are in deeper waters.

[33] Time-averaged currents on the continental shelf are often less than $10 \mathrm{~cm} / \mathrm{s}$, but intermittent strong currents greatly enhance sediment erosion and dispersal. For example, a net cross-shore flux of $340 \mathrm{~kg} / \mathrm{cm}$, in the offshore direction, was calculated for the 40-m-deep site of the narrow shelf during the 10-day period in January 1998 (Figure 6). The highest instantaneous flux for the $40-\mathrm{m}$ site $(3.5 \mathrm{~g} / \mathrm{cm} \mathrm{s})$ was calculated on January 19, when wave energy was low but off-shelf currents reached their peak of $24 \mathrm{~cm} / \mathrm{s}$ (see Figures 5 and $6 \mathrm{~d}$ ). Wave heights reached their peak on January 20, but cross-shelf flux decreased $(2.9 \mathrm{~g} / \mathrm{cm} \mathrm{s})$ as current velocities decreased (Figures 5 and 6 ).
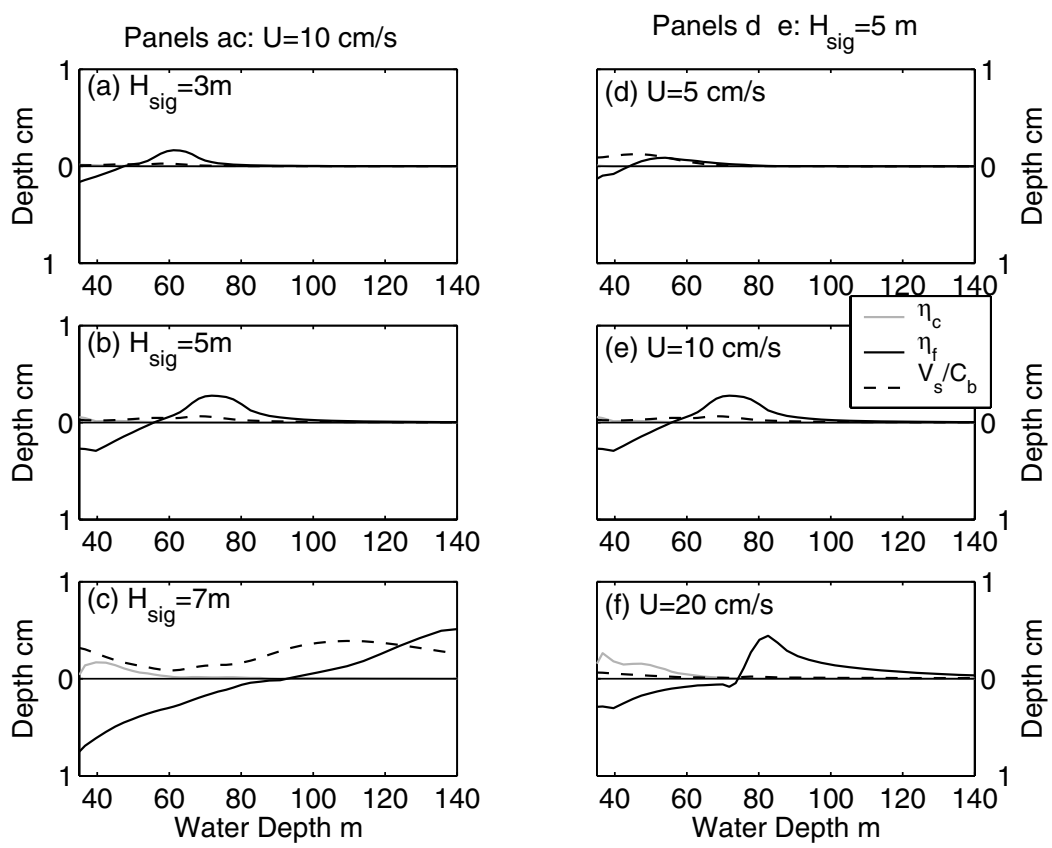

Figure 9. Sediment inventories for steep, narrow shelf after three days of steady forcing. Bed sediment represented by $\eta_{c}$ and $\eta_{f} ; \eta_{c}<0$ or $\eta_{f}<0$ indicates net erosion of the coarse $(>63 \mu \mathrm{m})$ or fine $(<63 \mu \mathrm{m})$ sediment, respectively. Values $>0$ indicate deposition. $V_{s} / C_{b}$ accounts for bed porosity and equals the thickness of the layer that would form if the suspended load settled. (a-c) Sediment inventories for steady currents $(u=10 \mathrm{~cm} / \mathrm{s})$ and wave heights are as follows: (a) $H_{\text {sig }}=3 \mathrm{~m}$, (b) $5 \mathrm{~m}$, and (c) $7 \mathrm{~m}$. (d-f) Calculations for steady wave heights $\left(H_{\text {sig }}=5 \mathrm{~m}\right)$ and currents are as follows: (d) $5 \mathrm{~cm} / \mathrm{s}$, (e) $10 \mathrm{~cm} / \mathrm{s}$, and (f) $20 \mathrm{~cm} / \mathrm{s}$. Figures $9 \mathrm{~b}$ and $9 \mathrm{e}$ are identical. 
[34] The following examples illustrate the sensitivity of erosional patterns to wave energy and current velocity. The "baseline case" is the steady-forcing example described in section 3, with constant wave heights of $5 \mathrm{~m}$ and geostrophic current velocities of $10 \mathrm{~cm} / \mathrm{s}$ ( $u=7 \mathrm{~cm} / \mathrm{s}$ off-shelf, $v=7 \mathrm{~cm} / \mathrm{s}$ poleward). Sediment inventories are compared for this case, and calculations are made using the same currents but wave heights of $3 \mathrm{~m}$ and $7 \mathrm{~m}$ (Figures $9 \mathrm{a}-9 \mathrm{c}$ ). More energetic waves recruit from a deeper layer of available sediment at a given water depth and entrain sediment from deeper water than less energetic waves. This accounts for the progressive deepening of the transition between net erosion to net deposition in Figures $9 a-9 c$. Erosional and depositional patterns are also sensitive to variations in current velocity. A second group of calculations use current velocities that range from $5-20 \mathrm{~cm} / \mathrm{s}$ (again directed offshore and poleward) and a wave height of $5 \mathrm{~m}$ (Figures 9d-9f). Higher currents transport suspended material farther than the less energetic currents; the location of the transition between erosion and deposition is sensitive to cross-shore current velocity (Figure 9).

[35] A potentially important contribution to gradients in crossshelf transport that has been neglected in these calculations is convergence and divergence in current velocity. Time series observations of current velocities made at four near-bed tripods on the Eel River shelf in 1996 recorded a convergence in crossshelf currents between water depths of 50 and $70 \mathrm{~m}$ [Wright et al., 1999]. Tests of the sensitivity of erosional and depositional patterns to such convergence indicate that such a feature may increase the thickness of event beds by a factor of 5 [Harris, 1999]. While indicative of increased net deposition, the specific bed thickness obtained in the convergent-current calculations is unreliable because the structure of the cross-shelf currents is not fully represented. A promising approach is to embed sediment transport calculations into a three-dimensional model of oceanographic circulation [see, e.g., Harris et al., 2000].

\subsection{Limits on Sediment Availability}

[36] Surface sediment texture responds quickly to increased shear stresses. Silty-sand beds are winnowed of fine sediment fractions within hours of the onset of resuspension events. Limits on sediment availability therefore cannot be ignored when estimating suspended sediment flux during transport events on the continental shelf. Properly constraining the amount of sediment available for resuspension requires that we understand the mechanisms that control the thickness of this layer. In our calculations, the depth of the available sediment layer typically ranges from a few millimeters over the middle and outer shelf, to less than a few centimeters over the inner shelf. Calculations that do not limit sediment availability predict resuspension of the fine fractions from unreasonable depths $(>10 \mathrm{~cm})$ below the sediment/water interface.

[37] Physical justifications exist for limiting sediment availability over both sandy and muddy beds, but the details of how such limits should be applied depends on substrate type and site-specific considerations. On sandy beds, the surficial sediment layer is envisioned to be a layer of actively migrating ripples or an upper-plane bed of moving grains. Sediment within these layers is considered to be available for entrainment into the overlying water column, whereas sediment below this layer is not. For sandy beds, the thickness of the active surficial layer seems well constrained by ripple height or depth of the bed load layer. Muddy sediment neither forms ripples nor travels as bed load, but mud beds exhibit increasing cohesive forces with depth in the seabed [Nichols and Biggs, 1985]. In our calculations, sediment sized $<45$ $\mu \mathrm{m}$ is assumed to be relatively easily eroded in the surface layer $\left(\tau_{c r}=1\right.$ dyne $\left./ \mathrm{cm}^{2}\right)$, but by allowing only the upper few millimeters to be entrained, we effectively impose a very high threshold for suspension of the material below the surficial layer. Once underlying layers are exposed, however, our formulation assigns them this same low suspension threshold. An alternative approach would account for the depositional history of the seabed; for example, muds that have been recently exhumed to the sediment/water interface might be initially overconsolidated, while recently deposited muds might be more erodible than muds that have been deposited for weeks or longer [see, e.g., Toorman, 1998].

\subsection{Patterns of Erosion and Deposition}

[38] The deposition rate at any location depends on a flux divergence term, $\partial Q_{x} / \partial x$, and a term that represents temporal changes in suspended sediment volume, $\partial V_{s} / \partial t$ (equation (2)). Aside from flux divergence that arises from the persistent crossshelf gradient in wave energy, divergence also depends on local and upstream sediment availability and the direction of the crossshelf current. If abundant fine-grained sediment is present across the shelf, the flux divergence term will be depositional when currents are directed off-shelf. If fine-grained sediment is not available in the inner shelf, however, the flux divergence term during an off-shelf directed flow will be erosive downstream of the winnowed area, where the flow first encounters fine-grained sediment. Conversely, when the flow is directed onshore, the flux divergence term is, in general, erosional at all water depths because the flow path goes from regions of lower to higher shear stresses.

[39] To demonstrate the significance of sediment availability on patterns of erosion and deposition, we apply the model to a shelf transect with a mid-shelf mud bed, based on the Eel River shelf, Northern California. This transect has the same bathymetry as the narrow shelf considered earlier but has a mud bed located between 50-90 m water depth (Figure 10). Observed surficial sediment texture of the Eel River shelf is used to specify the initial grain size distribution of the muddy sediment [Drake, 1999]. Suspended sediment flux and bed evolution are calculated for the period shown in Figure 5. Unlike the earlier example that used an initially uniformly graded transect, the highest sediment erosion rates in this case are calculated at the nearshore edge of the mud bed, in $50-60 \mathrm{~m}$ of water (Figure 11). Bed shear stresses are about half as much at this location as they are at a shelf depth of $40 \mathrm{~m}$ (Figure $5 \mathrm{~d}$ ), and thickness of the available layer of surficial sediments is slightly lower in the mid-shelf $(\sim 0.5-1 \mathrm{~cm})$ than the 40 -m site $(\sim 1$ $\mathrm{cm})$. The depth of erosion, however, is predicted to be $3.6 \mathrm{~cm}$ at a water depth of $60 \mathrm{~m}$, while it is only $0.7 \mathrm{~cm}$ in $40 \mathrm{~m}$ water depth (Figure 11). Much of the sediment finer than 45 that is eroded from the mid-shelf mud-bed is transported offshore, and accounts for deposition of $8 \mathrm{~mm}$ on the outer shelf $(70-100 \mathrm{~m})$, and significant export to the continental slope. Coarser silt $(45-63 \mu \mathrm{m})$ is also transported offshore but remains on the shelf with the net transport pattern being removal from the mid-shelf and deposition in water depths of $70-80 \mathrm{~m}$.

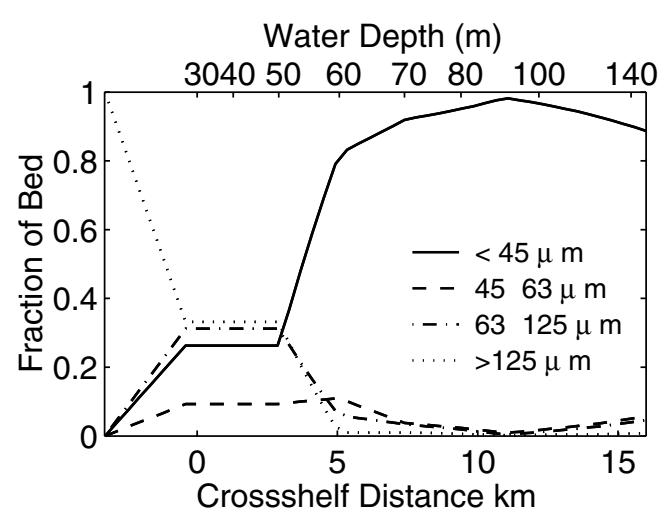

Figure 10. Grain size distribution for cross-shelf transect that includes a mid-shelf mud bed. Size distribution based on measurements from the $50,60,70$, and $90 \mathrm{~m}$ isobaths of the "Stransect" of the Eel River Shelf, Northern California [Drake, 1999]. 

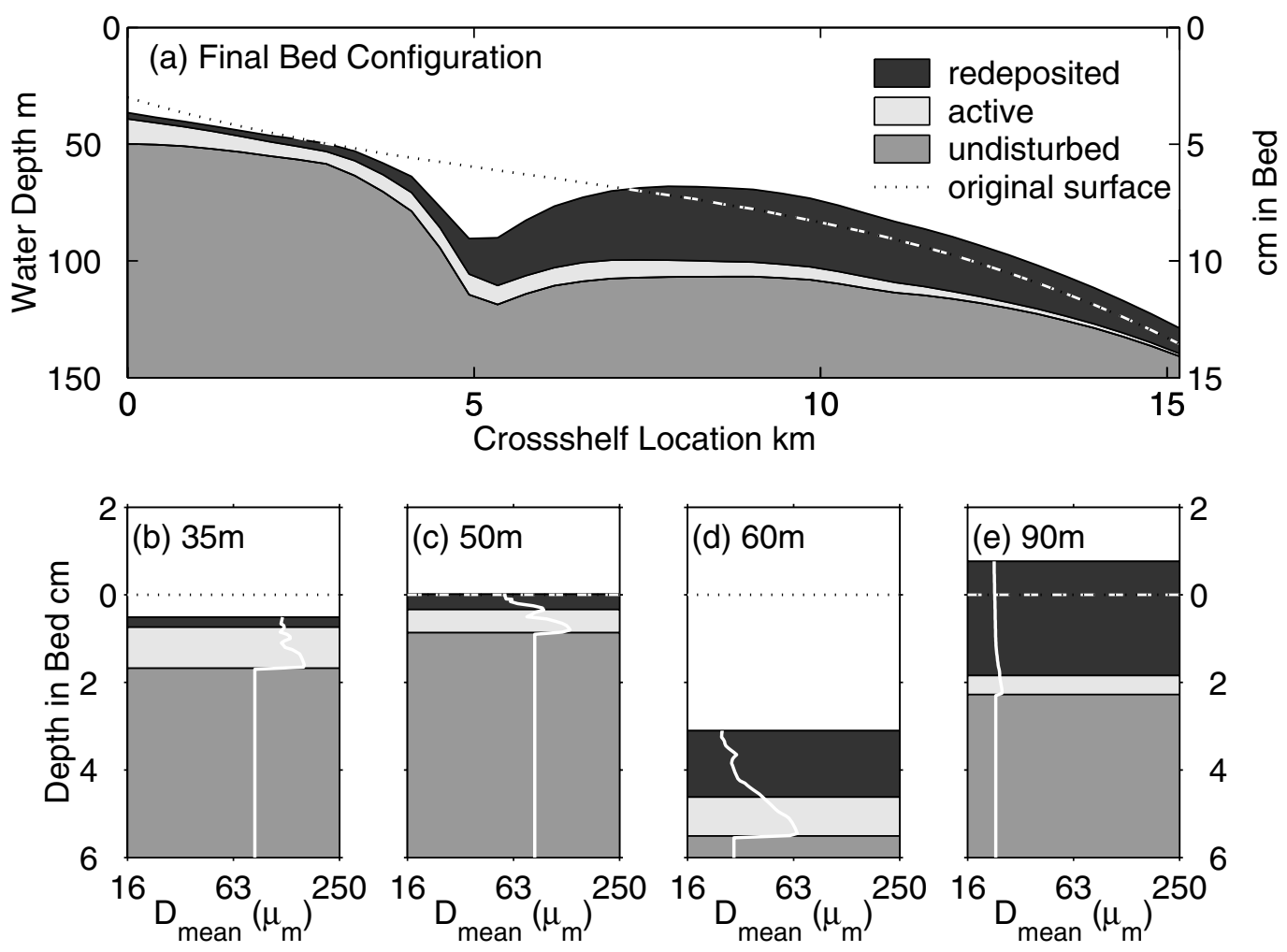

Figure 11. Final configuration of narrow, steep shelf that contains a mid-shelf mud bed (Figure 10) as reworked by the time series shown in Figure 5. See Figure 7 for explanation of Figures 11a-11e.

[40] The limited availability of silts on the inner shelf, along with the cross-shelf gradient in wave shear stress can create a sharp transition between sands and silts. Fine-grained sediments have a short residence time on the inner shelf, where they are frequently suspended by energetic wave shear stresses. Nearly all of our calculations remove all of the fine-grained sediment fraction from the active layer on the inner shelf, and those that were driven by off-shelf directed currents often develop a sharp transition between the "erosional" (sandy) and "depositional" (silty) areas. The calculations that are driven using realistic waves and currents create a sharp transition in grain size of surficial sediment within a 10-day time period.

[41] The thickest storm bed that these calculations create is thinner than $4 \mathrm{~cm}$ and stands little chance of being preserved intact in the stratigraphic record. Instead, bioturbation and physical reworking by subsequent storms are likely to eliminate any distinct bedding. In the case of the wide shelf, where suspension and redeposition of local sediment account for most of the reworking of the bed, almost no evidence of a storm bed would persist. On a narrow shelf, however, advection of coarse silts from the inner shelf to the mid-shelf may leave an observable change in the inventory of sediment in the bed, even after remixing. These conclusions, drawn from our calculations, are consistent with observations that shelf sedimentary records can preserve these types of textural signatures over timescales that range from seasonal [Drake, 1999] to geologic [Leithold, 1989].

4.4. Implications of These Processes over Longer Timescales

[42] To investigate the longer-term effect of redistribution by resuspension, the calculations are run for a 120-day period using wave and current forcing observed from the Eel River shelf [Ogston and Sternberg, 1999; Harris, 1999]. During this time, currents fluctuate between about $\pm 50 \mathrm{~cm} / \mathrm{s}$, and net currents are directed off-shelf. The shelf is subjected to several resuspension events, but the majority of the transport occurs during a few energetic wave events that account for less than 5 days of the 120 day record. This is consistent with point measurements that have observed flux to be highly episodic and wave-dominated [see, e.g., Ogston and Sternberg, 1999; Sherwood et al., 1994].

[43] For this 120-day period, these calculations predict that fine-grained material is removed from all shelf depths and delivered to the continental slope. A great deal of $<45 \mu \mathrm{m}$ sediment is removed from the shelf during a short time period of highly energetic waves that coincide with off-shelf directed, fast currents. Most of the coarse silt and fine sand $(63-125 \mu \mathrm{m})$ remain on the shelf but are transported toward deeper water, with erosion shoreward of $50 \mathrm{~m}$ water depth, and deposition between $50-120 \mathrm{~m}$ water depth. While the behavior of the coarse silts and sands are consistent with time series of grain size inventories, observations that clays and fine silts persist at mid-shelf locations on the Eel River shelf during this time contradict our predictions [Drake, 1999].

[44] The ability of inner- and mid-shelf wave energy to suspend sediment and that of shelf currents to remove sediment to the continental slope implies that fine-grained sediment should not remain in mid-shelf environments. The persistence of fine-grained sediment on shelves offshore of major river systems implies that other processes act to retain sediment in these areas. Such "mud beds" are locations where a good deal of silts and clays are deposited, and perhaps the delivery processes more than keep pace with the removal processes that are accounted for by these calculations. Our calculations, however, remove thick layers of mud deposits within a timescale of a few months, whereas individual flood beds have been observed to persist for up to a few years [Drake, 1999; Wheatcroft and Borgeld, 2000]. Our calculations do not fully account for cohesive forces and bioturbation, both of which may increase the residence time of muddy sediment in mid-shelf regions. These mechanisms are active over time periods longer than a single storm and, if accounted for, would decrease our predicted removal rates of fine silts and clays 
and improve our agreement with the time series sediment inventories of [Drake, 1999].

\section{Conclusions}

[45] Wave orbital velocities at the seafloor decrease with increasing water depth. Gradation in sediment texture from the mid- to outer continental shelf generally does not compensate for this decrease in bed shear stress, as shown using sediment data from the Eel River shelf (Figure 1). This implies that the frequency of resuspension and the magnitude of bed shear stress decreases seaward across the shelf. Cross-shelf gradients in wave-generated bed shear stress have several implications for sediment transport and storm-bed thickness, particularly on narrow shelves. Transport across a continental shelf results in time-dependence of flux because the flow path traverses a range of bed shear stresses. High bed shear stresses on the inner shelf combined with off-shelf currents are effective at removing fine sediment from the inner shelf. Fluctuations in the cross-shelf component of current velocity, combined with cross-shelf gradients in bed shear stress produce a net drift of sediment toward deeper water. On less steep, wide shelves, peak wave energy determines event bed thickness. On such shelves, the flux divergence term that results from the crossshelf gradient in wave energy is small. On narrow shelves, redistribution and flux convergence of fine-grained sediment enhances the thickness of storm beds formed at mid-shelf depths over short timescales. In the absence of mechanisms such as consolidation and cohesion that limit erosion rates of muds, and in the absence of re-supply of fine material by rivers, these calculations suggest that, over time, all of the fine silts and clays would be removed from the shelf and delivered to the continental slope.

[46] Resuspension and transport involves an interaction between the sediment suspended in the water column and sediment that remains on the seabed. As fine grained sediment is winnowed and advected downstream, the seafloor becomes coarsened and unable to supply fine-grained sediment for suspension. Cross-shelf gradations in sediment size develop on an initially ungraded bed as a result of cross-shelf gradients in sediment flux. Cross-shelf textural variations in turn affect fluxes. Suspended sediment calculations that neglect seabed winnowing will be inaccurate within hours of the onset of resuspension. The limits of sediment availability are as important in determining sediment transport rates and seabed reworking rates as are the presence and magnitude of energetic waves.

[47] Acknowledgments. This was supported by the Office of Naval Research's Geology and Geophysics program under the guidance of Joe Kravitz, in conjunction with the STRATAFORM project. The first author greatly appreciates support from U.S. Geological Survey in the form of a postdoctoral fellowship during development of this manuscript. Comments from Dave Rubin and Rich Signell of the U.S.G.S, Dave Drake of Drake Marine Consulting, and an anonymous reviewer have improved this work.

\section{References}

Borgeld, J. C., Holocene stratigraphy and sedimentation on the northern California continental shelf, Ph.D. thesis, Univ. of Washington, Seattle, Wash., 1985.

Butman, B., M. A. Noble, and D. W. Folger, Long-term observations of bottom current and bottom sediment movement on the Mid-Atlantic continental shelf, J. Geophys. Res., 84, 1187-1205, 1979.

Cacchione, D. A., P. L. Wiberg, J. F. Lynch, J. D. Irish, and P. A. Traykovski, Estimates of suspended-sediment flux and bedform activity on the inner portion of Eel River continental shelf, Mar. Geol., 154, 83-97, 1999

Drake, D. E., Temporal and spatial variability of the sediment grain-size distribution of the Eel shelf: The flood layer of 1995, Mar. Geol., 154, 169-182, 1999.

Drake, D. E., and D. A. Cacchione, Seasonal variation in sediment transport on the Russian River shelf, California, Cont. Shelf Res., 4, 495-514, 1985.
Field, M. E., J. H. Barber Jr., D. A. Cacchione, D. E. Drake, and F. L. Wong, Holocene sediment map of the central California continental shelf, tech. rep., U.S. Dep. of the Interior, U.S. Geol. Surv., Denver, Colo., 1992.

Griggs, G. B., and J. R. Hein, Sources, dispersal, and clay mineral composition of fine-grained sediment off central and northern California, J. Geol., 88, 541-566, 1980 .

Harris, C. K., The importance of advection and flux divergence in the transport and redistribution of continental shelf sediment, Ph.D. thesis, Univ. of Virginia M, Charlottesville, Va., 1999.

Harris, C. K., and R. P. Signell, Circulation and sediment transport in the vicinity of the Hudson shelf valley, in Estuarine and Coastal Modeling, VI, edited by M. L. Spaulding et al., pp. 380-394, Waterway, Port, Coastal and Ocean Div. of the Am. Soc. of Civ. Eng., New Orleans, LA, 1999.

Harris, C. K., and P. L. Wiberg, Approaches to quantifying long-term continental shelf sediment transport with an example from the northern $\mathrm{Ca}$ lifornia STRESS mid-shelf site, Cont. Shelf Res., 17, 1389-1418, 1997.

Harris, C. K., and P. L. Wiberg, A two-dimensional, time-dependent model of suspended sediment transport and bed reworking for continental shelves, Comp. Geosci., 27, 675-690, 2001.

Harris, C. K., W. R. Geyer, and R. P. Signell, Dispersal of flood sediment by oceanographic currents and energetic waves, Eos Trans. $A G U, 80(49)$, Ocean Sci. Meet. Suppl, 281, 2000.

Hill, P. S., and I. N. McCave, Suspended particle transport in benthic boundary layers, in The Benthic Boundary Layer: Transport Processes and Biogeochemistry, edited by B. P. Boudreau and B. B. Jorgensen, pp. 78-103, chap. 4, Oxford Univ. Press, New York, 2001

Kachel, N. B., and J. D. Smith, Sediment transport and deposition on the Washington continental shelf, in Coastal Oceanography of Washington and Oregon, edited by M. R. Landry and B. M. Hickey, pp. 287-348. Elsevier Sci., New York, 1989.

Leithold, E. L., Depositional processes on an ancient and modern muddy shelf, northern California, Sedimentology, 36, 179-202, 1989.

Li, M. Z., and C. L. Amos, SEDTRANS92: A sediment transport model for continental shelves, Comp. and Geosci., 21, 533-554, 1995.

Li, M. Z., and C. L. Amos, SEDTRANS96: The upgraded and better calibrated sediment-transport model for continental shelves, Comp. and Geosci., 27, 619-645, 2001

Lyne, V. D., B. Butman, and W. D. Grant, Sediment movement along the U.S. east coast continental shelf, II, Modeling suspended sediment concentration and transport rate during storms, Cont. Shelf Res., 10, 429461, 1987.

Maa, J. P., L. P. Sanford, and J. P. Halka, Sediment resuspension characteristics in the Baltimore Harbor, Mar. Geol., 146, 137-145, 1998.

Nichols, M. M., and R. B. Biggs, Estuaries, in Coastal Sedimentary Environments, edited by R. A. Davis, pp. 77-186, chap. 2, Springer-Verlag, New York, 1985.

Nittrouer, C. A., and L. D. Wright, Transport of particles across continental shelves, Rev. Geophys., 32, 85-113, 1994.

Nittrouer, C. A., R. W. Sternberg, R. Carpenter, and J. T. Bennett, The use of ${ }^{210} \mathrm{~Pb}$ geochronology as a sedimentological tool: Application to the Washington continental shelf, Mar. Geol., 31, 297-316, 1979.

O'Grady, D. B., J. F. Sarg, L. F. Pratson, and J. P. M. Syvitski, Preliminary morphological classification of modern continental margins and possible links to formational processes, in Annual Meeting Abstracts with Programs, vol. 30, p. 364, Geol. Soc. of Am., Boulder, Colo., 1998.

Ogston, A. S., and R. W. Sternberg, Sediment transport events on the northern California continental shelf, Mar. Geol., 154, 69-82, 1999.

Rubin, D. M., and D. J. Topping, Quantifying the relative importance of flow regulation and grain-size regulation of suspended sediment transport $\alpha$, and tracking changes in bed-sediment grain size $\beta$, Water Resour. Res., $37,133-146,2001$.

Sherwood, C. R., B. Butman, D. A. Cacchione, D. E. Drake, T. F. Gross, R. W. Sternberg, P. L. Wiberg, and A. J. Williams, III, Sediment transport events on the northern California continental shelf during the 1990-1991 STRESS experiment, Cont. Shelf Res., 14, 1063-1100, 1994.

Smith, J. D., Modeling of sediment transport on continental shelves, in The Sea, vol. 6, Marine Modeling, edited by E. D. Goldberg et al., pp. 539577, chap. 13, John Wiley, New York, 1977.

Smith, J. D., and T. S. Hopkins, Sediment transport on the continental shelf off of Washington and Oregon in light of recent current measurements, in Shelf Sediment Transport, edited by D. J. P. Swift et al., pp. 143-180, chap. 7, Dowden, Hutchinson, and Ross, Stroudsburg, Penn., 1972.

Sommerfield, C. K., and C. A. Nittrouer, Modern accumulation rates and a sediment budget for the Eel River shelf, USA: A flood-dominated depositional environment, Mar. Geol., 154, 227-241, 1999.

Sternberg, R. W., and L. H. Larsen, Frequency of sediment movement on the Washington continental shelf: A note, Mar. Geol., 21, M37-M47, 1976. Sternberg, R. W., I. Berhane, and A. S. Ogston, Measurement of size and settling velocity of suspended aggregates on the northern California continental shelf, Mar. Geol., 154, 43-53, 1999. 
Toorman, E. A., Sedimentation and self-weight consolidation: Constitutive equations and numerical modeling, Geotechnique, 49, 709-726, 1998.

Wheatcroft, R. A., and J. C. Borgeld, Oceanic flood deposits on the northern California shelf: Large scale distribution and small-scale physical properties, Cont. Shelf Res., 20, 2059-2066, 2000.

Wiberg, P. L., D. E. Drake, and D. A. Cacchione, Sediment resuspension and bed armoring during high bottom stress events on the northern $\mathrm{Ca}$ lifornia continental shelf: Measurements and predictions, Cont. Shelf Res., 14, 1191-1219, 1994.
Wright, L. D., S. C. Kim, and C. T. Friedrichs, Across-shelf variations in bed roughness, bed stress and sediment suspension on the northern California shelf, Mar. Geol., 154, 99-115, 1999.

Courtney K. Harris, Virginia Institute of Marine Science, P.O. Box 1346, Gloucester Point, VA 23062-1346, USA.

Patricia Wiberg, Department of Environmental Sciences, Clark Hall, University of Virginia, Charlottesville, VA 22903, USA. 